\title{
Relasi Terorisme dan Media
}

\author{
Oleh: Fajar Junaedi ${ }^{1}$
}

\begin{abstract}
Terrorism is the major issue in the recent years. As political communications forms, terrorism can only have significance as a communication act if the action of terrorism group transmitted through the mass media to the large audience. Terrorist did violence and other terror actions in order to get support from public, make fearness for institutional government and raise funding from their supporters.
\end{abstract}

Keywords : terrorism, media, publicity

"I can't believe the news today

Oh, I can't close my eyes and make it go away

How long, how long must we sing this song?

How long, how long?

Tonight, we can be as one tonight.....

And the battle's just begun

There's many lost, but tell me who has won

The trench is dug within our hearts

And mothers, children, brothers, sisters torn apart...

And it's true we are immune

When fact is fiction and TV reality

And today the millions cry

We eat and drink while tomorrow they die, yeah"

(U2, Sunday Bloody Sunday)

Beberapa tahun belakangan ini, isu terorisme menjadi isu yang acapkali menjadi isu dominan dalam wacana publik. Berbagai media, mulai dari media cetak, media elektronik, sampai dengan media internet memberitakan berbagai aksi terorisme yang terjadi di berbagai daerah di Indonesia. Aksi bom di Bali dan JW Marriot serta penangkapan pelaku terorisme yang seringkali diiringi dengan baku tembak antara aparat

1 Dosen Ilmu Komunikasi Universitas Muhammadiyah Yogyakarta 
keamanan dengan pelaku terorisme adalah beberapa isu yang pernah dibingkai (framing) oleh media dalam pemberitaannya tentang terorisme.

Bagi para teroris, media memiliki posisi penting dalam usaha mengkampanyekan isu-isu yang mereka perjuangkan. Brian McNair memaparkan bahwa teror adalah sebuah bentuk komunikasi politik, yang dilakukan di luar prosedur konstitusional. Para teroris mencari publisitas untuk membawa tujuan psikologis mereka ke benak khalayak. Mereka menggunakan kekerasan untuk menghasilan berbagai efek psikologis seperti demoralisasi musuh, mendemosntrasikan kekuatan gerakan mereka, mendapatkan simpati publik dan menciptakan ketakutan dan chaos. Untuk mencapai tujuan ini, para teroris harus mempublikasikan aksi mereka (Paletz dalam McNair,1999:173).

Kata teror dan teroris sendiri sebenarnya bisa berartikulasi dalam berbagai konteks. Noam Chomsky misalnya, merujuk pada terorisme negara (state terrorism) untuk melabeli berbagai aksi kekerasan yang dilakukan oleh pemerintah Amerika Serikat dalam berbagai aksi inetrenasionalnya, seperti yang terjadi di Vietnam, Irak, dan Afganistan. Namun bagi pemerintah Amerika Serikat, yang layak diberi label teroris adalah kelompok-kelompok yang dianggap membahayakan kepentingan nasional dan internasional negara adikuasa ini, seperti Al Qaida dan Taliban yang menjadi musuh utama militer Amerika Serikat mulai awal milenium kedua ini.

Sebagai jalan tengah, kata "teroris" dapat digunakan untuk merujuk pada organisasi di mana anggotanya melabeli diri mereka sebagai "pejuang kemerdekaan", "tentara gerilya" atau "pejuang revolusioner". Aksi mereka ini umumnya dalam bentuk aksi bom bunuh diri, pembunuhan, penculikan, serangan bersenjata, pembajakan pesawat dan sejenisnya. Aksi-aksi ini tidak bisa dilihat semata-mata sebagai aksi kekerasan, namun lebih merupakan bentuk komunikasi politik yang berwujud pada penggunaan kekerasan, yang dilakukan di luar prosedur resmi (Mcnair,1995:172).

Aksi yang dilakukan oleh Tentara Pembebasan Irlandia (IRA) pada dekade 1970-an seringkali mendapat porsi peliputan yang besar di berbagai media massa di Inggris Raya. Kelompok yang memperjuangkan kemerdekaan Irlandia ini sengaja menggunakan taktik perang kota dan bom bunuh diri untuk mendapatkan perhatian publik atas aksi yang mereka lakukan. Pasca aksi teror yang mereka lakukan, IRA selalu membuat pernyataan resmi bahwa aksi yang terjadi adalah berada di bawah komando mereka. Pernyataan ini diselingi dengan isu-isu yang mereka tuntut kepada pemerintah Inggris. 
Di tahun 1972, tepatnya pada tanggal 30 Januari dua puluh tujuh orang ditembak oleh Resimen Lintas Udara Kerajaan Inggris saat parade demo yang mereka lakukan untuk memprotes pendudukan Inggris di Irlandia. Insiden ini kemudian memicu semakin berkembangnya sentimen anti Inggris di Irlandia, yang kemudian dimanifestasi dalam bentuk Irish Republican Army's (IRA) yang mengkampanyekan perlawanan terhadap pendudukan Inggris dengan melalui jalan militer dan kekerasan, termasuk dengan melakukan aksi terorisme untuk mendapatkan dukungan publik. Dukungan publik ini diharapkan datang dari pemberitaan media massa yang memberitakan aksi dan tuntutan mereka. Salah satu keprihatinan publik, dan juga simpati publik terhadap para korban insiden berdarah ini berasal dari band papan atas U2 melalui lagunya Sunday Bloody Sunday.

Model aksi kekerasan seperti ini kemudian banyak ditiru oleh kelompok perlawanan yang menggunakan aksi kekerasan untuk mencapai tujuannya. Karena menggunakan aksi kekerasan inilah, label teroris kemudian dilekatkan oleh pemerintah terhadap berbagai kelompok perlawanan yang menggunakan aksi kekerasan.

Aksi kekerasan yang dilakukan oleh kelompok teroris selain untuk menimbulkan efek teror dan ketakutan kepada lawan politiknya, juga ditujukan untuk beberapa motif lain, seperti untuk membangun agenda media yang memberitakan isu yang mereka perjuangkan, mendulang dukungan publik yang senasib maupun menggalang dukungan finansial dari para donaturnya.

\section{Kelompok Teroris Sebagai Aktor Politik}

Organisasi politik seringkali disebut sebagai aktor politik. Aktor politik sendiri didefinisikan sebagai individu-invidu yang menyalurkan aspirasinya melalui perangkat organisasi dan lembaga, untuk mempengaruhi proses pengambilan keputusan. Individu ini bisa jadi terlibat dalam proses ini dengan berusaha mendapatkan kekuasaan dalam lembaga politik resmi, seperti melalui pemerintahan maupun lembaga legislatif di mana melalui lembaga seperti inilah kebijakan dalam diterapkan (McNair, 1999: 5). Organisasi politik ini meliputi partai politik, kelompok penekan dan kelompok teroris.

Partai politik adalah bagian penting dalam organisasi politik. Melalui partai politik terjadi agregasi kepentingan anggota-anggotanya, yang secara kolektif menyepakati struktur dan ideologi partai politik untuk mencapai tujuan bersama. Bentuk kedua dari aktor politik adalah kelompok penekan (pressure group). Kelompok penekan berbeda dengan organisasi publik, karena tidak 
begitu terinstitusionalisasi dan acapkali lebih "politis" dalam menyuarakan kepentingannya serta memiliki kepedulian terhadap isu-isu tertentu seperti konservasi lingkungan, pelestarian hewan langka. Kelompok penekan ini biasanya hanya berfokus pada satu isu saja, seperti yang terjadi dalam gerakan anti nuklir di Inggris pada awal dekade 1980-an (McNair,1999:9).

Di negara-negara Eropa Barat, kelompok penekan ini ada yang kemudian bermetamorfosis menjadi partai politik. Metamorfosis yang berhasil adalah proses yang dilakukan gerakan lingkungan dengan membangun partai "Hijau". Partai ini berhasil meraih simpati besar dengan berhasil mendudukan wakil-wakilnya di lembaga legislatif di Jerman dan beberapa negara lain di Eropa (McNair,1999:9).

Dalam kegiatan komunikasi politiknya, kelompok penekan lebih sering menggunakan berbagai bentuk strategi periklanan dan humas untuk menyuarakan kepentingannya. Dibandingkan dengan partai politik, kelompok penekan secara finansial lebih terbatas kemampuannya, maka kelompok penekan dihadapkan pada keharusan untuk memiliki kemampuan lebih dalam aktivitas humas dan iklan yang mereka lakukan. Dalam demonstrasi yang mereka lakukan, kelompok penekan berusaha agar aksi yang mereka lakukan mendapat perhatian dari para jurnalis dengan melakukan aksi teatrikal dan melengkapi aksi mereka dengan spanduk yang unik.

Bentuk lain dari organisasi politik yang paling ekstrim di luar partai politik dan kelompok penekan adalah organisasi teroris. Sebagaimana yang telah disinggung di bagian awal, terminologi teroris mungkin masih sangat diperdebatkan, karena bagi para pendukung kelompok teroris, aksi terorisme mungkin bisa diterima sebagai bentuk perjuangan politik, sedangkan bagi yang lain apapun alasannya terorisme adalah tindakan terkutuk. Tindakan yang dilakukan oleh Jamaah Islamiyah yang dikomandani oleh Noordin M. Top dengan melakukan serangkaian pemboman di Bali dan Jakarta dari tahun 2002 sampai 2009 bagi para pendukungnya dianggap sebagai "jihad", namun bagi umat Islam lainnya apa yang dilakukan oleh kelompok ini bukanlah jihad.

Di tengah beragam artikulasi tentang kelompok teroris ini, bisa diambil sebuah jalan tengah untuk mendefinisikan kelompok teroris, yaitu dengan merujuk terminologi ini pada kelompok yang menggunakan taktik teror, seperti pemboman, pembajakan dan penculikan sebagai metodemetode utama untuk meraih tujuan politiknya.

Aksi dari metode yang digunakan oleh kelompok teroris ini disebut sebagai terorisme, sebuah tindakan yang telah menyebar luas melewati 
batas negara-bangsa. Di Inggris Raya yang notabene negara telah mapan secara politik, aksi terorisme yang dilakukan oleh kelompok separatis juga masih ditemui, sebagaimana aksi terorisme yang dilakukan oleh IRA, sebelum perjanjian damai tahun 1998 yang telah banyak merenggut nyawa penduduk sipil tidak berdosa. Ini menunjukan bahwa terorisme bukan semata-mata fenomena yang terjadi di negara berkembang seperti yang sering terjadi di Timur Tengah, Asia Selatan dan Asia Tenggara.

Aksi terorisme yang paling fenomenal bahkan terjadi di negara adikuasa Amerika Serikat. Aksi terorisme paling fenomenal ini adalah saat Al Qaeda membajak pesawat dan menabrakannya ke gedung kembar World Trade Center (WTC) di New York pada tanggal 11 September 2001. Aksi yang terekam dengan kamera televisi ini tersebar ke seluruh dunia dan memantik aksi kontra terorisme oleh pemerintahan Amerika Serikat melalui aksi polisional perang melawan teror di Afganistan dan Irak.

Dalam usaha menyebarkanide-idenya, kelompokterorismenggunakan metode humas dan manajemen media untuk mengartikulasikan kepentingannya seperti dengan mengeluarkan rilis dan konferensi press. Perkembangan internet, terutama yang berbasis web 2.0 semakin memodernisasi kemampuan kelompok teroris untuk menyebarkan idenya. Di masa sekarang ini, media baru yang berbasis internet web 2.0, yang memungkinkan interaktivitas dari para audiensnya semakin membuat para pelaku aksi terorisme semakin mudah untuk menyebarkan gagasannya melalui publisitas dengan menggunakan platform media internet. Untuk menyebarkan gagasan tertulis, blog menjadi media yang murah dan mudah dibuat. Demikian juga untuk menyebarkan video testimoni atas aksi yang mereka lakukan, kelompok teroris cukup menggunakan situs video sosial youtube.Namun demikian, media baru dengan platform internet ini belum sepenuhnya mengganti media konvensional, baik dalam bentuk cetak maupun elektronik. Jangkauan yang lebih luas dari media cetak dan elektronik menjadikan dua jenis media ini masih tetap menjadi pilihan bagi kelompok teroris untuk mengkampanyekan gagasan-gagasannya.

Kelompok teroris, dalam posisinya sebagai komunikator dalam proses komunikasi, berada dalam ranah pinggir (marginal). Jika dilihat dari proses komunikasi politik, kelompok teroris bisa disebut sebagai aktor politik marjinal, yang beroperasi di luar institusi yang mapan. Keompok teroris berada dalam posisi yang tidak menguntungkan jika dibandingkan dengan partai politik, pemerintah dan aparat negara (McNair,1995:155). 
Di berbagai kasus, posisi yang tidak menguntungkan dari kelompok teroris ini berimplikasi pada tekanan yang dilakukan oleh aparat negara, militer, dan dunia internasional. Tekanan ini juga akan merembet ke negara-negara yang dianggap melindungi kelompok teroris. Libya adalah salah satu negara yang pernah bertahun-tahun dikucilkan dari pergaulan internasional dan bahkan mendapat embargo ekonomi karena dituduh melindungi pelaku pengeboman pesawat Pan Am, yang juga dikenal dengan pengeboman Lockerbie atau bencana udara Lockerbie pada tanggal 21 Desember 1988 atas pesawat Boeing 747-100 milik maskapai Pan Am dari Amerika Serikat. Setelah investigasi selama tiga tahun, tuduhan pembunuhan diarahkan pada Abdelbase Ali Mohmed Al Megrahi, seorang pejabat intelijen Libya dan kepala keamanan untuk Libyan Arab Airlines (LAA), dan Al Amin Khalifa Fhimah, stasiun manajer LAA di Bandara Luqa, Malta.

Karena label teroris sudah lazim dilekatkan juga dengan label subversi dan ancaman keamanan bagi negara, tidak mengherankan jika kelompok teroris memiliki keterbatasan dalam akses dengan media. Ini berbeda dengan kelompok penekan yang lain seperti lembaga swadaya masyarakat yang masih memiliki akses yang kuat untuk mengembangkan publisitas.

\section{Publisitas Terorisme}

Media massa adalah elemen penting dalam proses komunikasi politik, karena tanpa media massa pesan politik tidak mampu menjangkau khalayak luas dalam waktu yang cepat dan sekaligus massif. Dalam sistem politik yang demokratis, fungsi media adalah sebagai saluran komunikasi politik yang awalnya berasal dari luar media itu sendiri dan sekaligus juga sebagai pengirim dari pesan-pesan politik yang dikonstruksi oleh jurnalis (McNair,1999:11).

Secara absolut, para aktor politik harus menggunakan media untuk mendapatkan dukungan dari khalayak, karena tanpa menggunakan media, khalayak tidak akan mengetahui aktor politik yang bermain di panggung politik. Kegiatan politik, program politik, pernyataan politik, dan sejenisnya tidak akan mencapai khalayak jika tidak menggunakan media massa. Ini kemudian membuat para aktor politik, mulai dari partai politik, kelompok penekan, organisasi massa dan juga kelompok teroris berusaha mendapat liputan media agar tujuan politik mereka terkomunikasikan dengan khalayak.

Bahkan di negara-negara maju, para politisi acapkali mempercayakan pengelolaan manajemen humas untuk berelasi dengan media massa dengan 
menggunakan konsultan humas yang profesional. Ini tentu tidak lepas dari usaha agar politisi bersangkutan mendapatkan porsi peliputan yang tinggi di media massa secara positif.

Perkembangan media baru berbasis internet semakin membuat peran media menjadi kian signifikan. Barrack Obama, Presiden Amerika Serikat pertama dari keturunan Afro-Amerika, berhasil meraih simpati pemilih dengan menggunakan situs pertemanan facebook. Setelah facebook dilarang di Iran, para pendukung oposisi di Iran menggunakan situs jaringan sosial twitter, untuk memberitakan berbagai peristiwa yang terjadi di negeri para mullah pasca pemilihan presiden 2009 yang diklaim oleh kaum reformis sebagai pemilu yang penuh kecurangan.

Media massa, tentu saja tidak hanya bisa dipahami sebagai institusi yang memberitakan dengan corak pemberitaan yang netral, karena dalam proses pemberitaan media di sekelilingnya selalu terdapat arena politik. Bagi penganut perspektif interpretatif, pemberitaan media adalah hasil konstruksi para jurnalis, editor dan sebagainya atas realitas yang terjadi. Jadi, realitas yang ada di media massa bukanlah realitas yang sesungguhnya.

Media massa kemudian dianggap "bias", dan istilah inilah yang kemudian memainkan peran penting dalam komunikasi politik dan sekaligus berdimensi politis. Adalah benar bahwa media massa berada dalam corak kapitalisme, namun adalah salah untuk menyatakan bahwa semua media bersifat kapitalistik. Ini penting untuk dipahami, karena dengan mendudukan media hanya semata-mata berada dalam corak kapitalisme, maka serempak juga akan menggangap media dan pekerja media yang ada di dalamnya sebagai pihak yang mendukung kelas berkuasa, seperti partai penguasa (ruling party) dalam komunikasi politik.

Berdasarkan kepemilikannya, media dapat dibagi dalam tiga bagian besar. Pertama, not-for-profit media organization. Media yang dikelola dalam manajemen model ini umumnya diorganisir atas dasar non profit oleh kelompok kepentingan seperti kelompok perempuan, etnis dsb, sebagai contoh adalah radio komunitas (resmi maupun tidak), zine, e-zine dsb. Media seperti ini lebih memiliki kebebasan dalam editorial dan isi, sehingga peran pekerja media sebagai agency, jika melihat manajemen media dalam teori strukturasi, menjadi lebih besar. Pekerja media, terutama para jurnalisnya, relatif lebih bebas dan leluasa mengartikulasikan ide-idenya.

Media seperti ini umumnya dimiliki oleh kelompok penekan, yang membebaskan dirinya untuk melakukan kritik terhadap kebijakan yang 
diambil oleh pemerintah dalam isu tertentu. Model manajemen media seperti ini yang ideal dalam kerangka membangun ruang publik, karena dengan model manajemen media seperti ini berbagai isu dan wacana dapat saling dibenturkan secara bebas. Persoalannya adalah media dengan model kepemilikan seperti ini terbatas secara kuantitas dan kualitas. Jumlah yang terbatas dan kemampuan bersaing dengan media yang berorientasi pada penumpukan laba adalah persoalan yang harus dihadapi oleh media dengan model kepemilikan seperti ini. Belum lagi kualitas dari manajemen medianya yang terbilang ketinggalan dengan media yang dimiliki oleh swasta.

Media konvensional seperti koran menuntut adanya jaringan distribusi yang kuat agar mencapai khalayak. Bagi kelompok teroris, jalur distribusi yang kuat ini tentu saja susah dicapai kecuali dalam beberapa kasus seperti di Palestina dimana kelompok perlawanan Hamas memiliki media cetak sendiri. Ini berbeda dengan di Indonesia misalnya, di mana kelompok teroris dianggap sebagai ancaman nasional sehingga keberadaannya selalu laten, sehingga menerbitkan media menjadi hal yang mustahil bagi mereka.

Kedua adalah organisasi media yang dimiliki oleh negara atau publik (public/state owned media organizations). Model kepemilikan organisasi media seperti ini mendudukan kontrol negara dalam posisi yang vital. Manajemen media dalam model kepemilikan seperti ini memainkan peran menjadikan media sebagai alat penanam ideologi negara dan hegemoni, sebuah fenomena sosial yang banyak dijumpai di negara komunis. Sedangkan public owned media mengindikasikan media digunakan untuk kepentingan publik, dengan dibiayai pajak langsung maupun tidak langsung, yang biasanya berfokus pada berita dan dokumenter seperti BBC di Inggris. Bentuk pertama dari organisasi media ini sangat tidak memungkinkan bagi kelompok teroris untuk menyuarakan gagasannya. Framing pemberitaan dari media yang dikuasai oleh negara secara mutlak akan membingkai aksi teroris sebagai aksi kekerasan yang tidak manusiawi dan mengancam keamanan nasional, tanpa ada tendensi pemberitaan dari media pemerintah untuk memberitakan isu politik yang disuarakan oleh kelompok teroris.

Terakhir adalah organisasi media yang dimiliki oleh swasta (privately owned media organizations). Model kepemilikan media ini mengindikasikan bahwa media dimiliki swasta, dikontrol oleh individu, keluarga, pemegang saham maupun holding company (Devereux,2003:55-56). Model kepemilikan yang terakhir inilah yang saat ini secara telak mendominasi, sehingga manajemen media pun tidak lepas dari kepentingan pemilik 
modal, sebagaimana yang dikemukakan penganut teori neo Marxisme namun dibantah oleh para penganut teori strukturasi yang mendudukan pekerja media dalam manajemen media sebagai pihak yang memiliki daya tawar terhadap manajemen dan pemilik media. Bagi bentuk media terakhir ini, mekanisme pasar menjadi jantung bagi kehidupan media. Untuk mendapatkan oplah yang besar maupun rating yang tinggi, media yang dimiliki swasta saling bersaing untuk membuat berita yang paling memiliki nilai berita (newsworthiness).

Bagi kelompok teroris, memahami tentang nilai berita menjadi faktor mutlak agar aksi yang mereka lakukan mendapat porsi pemberitaan yang besar. Nilai berita bisa digambarkan sebagai berikut. Pertama, timeliness yaitu adanya aktualitas (peristiwa/perkembangan baru). Kedua, proximity yaitu adanya kedekatan (geografis, emosional) dengan pembaca, relevansi bagi pembaca. Ketiga, conflict yaitu adanya konflik fisik (perseteruan antarkelompok) dan non fisik (perbedaan pendapat). Keempat, eminence and prominence yaitu menyangkut peristiwa/orang terkenal. Kelima, consequence and impact, yaitu berdampak pada kehidupan pembaca. Terakhir, human interest yaitu menarik perhatian dan menyentuh perasaan khalayak (Itule dan Anderson, 2007:10).

Merujuk tentang nilai berita di atas, kita bisa memahami mengapa Jammah Islamiyah melakukan pengeboman di Bali, bukan di kota-kota lain. Tentu saja alasannya dalah faktor proximity karena di Bali banyak wisatawan asing. Aksi yang dilakukan di Bali akan mendapat porsi pemberitaan yang jauh lebih besar dibandingkan jika dilakukan di kota-kota lain.

Jika dipetakan, ada beberapa alasan yang membuat para teroris memerlukan media massa dan bagaimana sebenarnya relasi media terhadap teroris. Pertama, kelompok teroris mememerlukan publisitas untuk meraih tujuan perjuangannya. Publisitas ini bukan publisitas yang dibeli, seperti advetorial misalnya, namun publisitas yang berusaha secara gratis mereka dapatkan dari pemberitaan atas aksi yang mereka lakukan. Raphel F. Perl (2007) menyebutkan bahwa dalam keadaan normal tidak mungkin para teroris melakukan pemasangan iklan di media massa, sehingga publisitas secara gratis menjadi pilihan yang paling realistis.

Bentuk publisitas lain yang ideal bagi kelompok teroris adalah wawancara (interview) di stasiun televisi secara langsung (live). Wawancara yang dilakukan secara langsung memperkecil kemungkinan adanya proses editing, sebagaimana jika dilakukan secara rekaman (taping). Melalui 
wawancara inilah, kelompok teroris dengan mudah mendapat porsi pemberitaan yang besar, meskipun wawancara hanya dilakukan melalui telepon. Sebuah pengalaman menarik terjadi ketika jaringan televisi kabel CNN melakukan wawancara dengan Usama Bin Ladin, yang dianggap sebagai pemimpin Al Qaida di bulan Mei 1997. Tokoh seperti Usama tentu memiliki nilai berita yang sangat tinggi, sehingga wawancara dengannya menjadi hal yang luar biasa, terutama dilihat dari segi akses eksklusif yang didapatkan jurnalis CNN terhadap figur ini.

Akses yang didapatkan oleh $\mathrm{CNN}$ dengan Usama melalui wawancara eksklusif yang mereka lakukan dan siarkan kepada publik akan berbanding lurus dengan nilai rating yang diperolehnya. Saat wawancara dengan tokoh sekaliber Usama disiarkan, perhatian publik akan tertuju kepada wawancara tersebut. Dalam konteks ekonomi politik media, CNN mendapat keuntungan dari pemasangan iklan dengan program yang memiliki rating yang tinggi, seperti wawancara dengan Usama.

Dalam komunikasi massa dikenal teori gelombang kebisuan dan opini publik (spiral of silence and public opinion theory) yang menyatakan bahwa publik akan cenderung mengikuti opini yang sedang berkembang, dan publik minoritas yang memiliki suara lain cenderung akan diam. Kita bisa melihat fenomena maraknya pemberitaan tentang terorisme dengan menggunakan perspektif teori ini. Jika, pemberitaan berbagai media massa banyak yang membingkai pemberitaan tentang terorisme, maka media lain yang sebenarnya ingin memberitakan isu lain di luar terorisme akan berfikir ulang untuk memberitakannya, karena perhatian publik akan lebih banyak tertuju pada pemberitaan tentang terorisme.

Kedua, terorisme memerlukan media untuk mendapatkan legitimasi dari publik bahwa aksi yang mereka lakukan lebih karena orientasi ideologis dan politis, bukan karena alasan individu atau personal. Memang, dalam banyak kasus terorisme, para pelaku aksi bom bunuh diriadalah para korban dari aksi pemerintah yang melakukan operasi militer terhadap terorisme atau setidaknya anggota masyarakat yang tidak bersepakat dengan ideologi dominan dan kebijakan negara. Namun demikian kelompok teroris lebih meyukai jika aksi yang mereka lakukan dibingkai dalam pemberitaan media massa sebagai aksi yang bernuansa politis dan ideologis.

Tidak mengherankan jika dalam berbagai aksinya, kelompok teroris segera menyebarkan video rekaman testimoni dengan mengirimkan kaset atau keping video ke media massa terutama televisi dengan harapan agar 
bingkai pemberitaan terhadap aksi yang mereka lakukan lebih ditekankan pada nuansa politis dan ideologis. Gerakan perlawanan Palestina yang menolak aksi zionisme Israel di Timur Tengah dikenal sebagai salah satu kelompok yang menggunakan gabungan aksi terorisme dan publisitas untuk mendapatkan perhatian publik.

Situs jejaring sosial seperti youtube semakin memudahkan kelompok teroris dalam usahanya membingkai pemberitaan yang sesuai dengan harapan mereka, walaupun mereka tidak duduk di meja redaksi. Jika sebelumnya, penayangan video rekaman dari kelompok teroris menjadi hak penuh dari redaksi stasiun televisi untuk menilainya layak atau tidak untuk ditayangkan, maupun perlu ada editing atau tidak, maka dengan adanya youtube, kelompok teroris memiliki kuasa sepenuhnya untuk menyiarkan rekaman videonya kepada publik tanpa ada sensor. Jika pun kemudian video tersebut disensor oleh situs sosial berbasis video ini karena ada keberatan dari pihak lain, belum tentu video tersebut akan berhenti beredar karena rekamannya sudah tersiarkan sebelumnya dan bisa jadi sudah diunduh oleh khalayak penggunanya.

\section{Daftar Pustaka}

Devereux, Eoin (2005). Understanding The Media. London, Sage

McNair, Brian (1995). An Introduction to Political Communication. London, Routhledge

Bruce D Itule and Douglas A Anderson (2007).News Writing \& Reporting for Today's Media. New York, Routhledge 